\title{
Epstein-Barr Capsid IgG Antibody Measurement
}

National Cancer Institute

\section{Source}

National Cancer Institute. Epstein-Barr Capsid Ig G Antibody Measurement. NCI

Thesaurus. Code C96600.

The determination of the amount of Epstein-Barr capsid IgG antibody present in a sample. 